\title{
PENGARUH RANTAI TATANIAGA TERHADAP EFISIENSI PEMASARAN DAGING SAPI DI KABUPATEN KARO
}

\author{
(The Influence of Chain Efficiency Marketing Beef Cattle in The Karo Regency)
}

\author{
Ridho Andhika', Hasnudi $^{2}$ dan Nurzainah Ginting ${ }^{2}$ \\ 1. Mahasiswa Program Studi Peternakan Fakultas Pertanian Universitas Sumatera Utara \\ 2. Staff Pengajar Program Studi Peternakan Fakultas Pertanian Universitas Sumatera Utara
}

\begin{abstract}
The research aims to find out the factor that affect the difference in the price of beef, the systematic distribution of beef, marketing system and efficiency marketing. The research was carried out in Karo district in 4 subdistrict (Tiga Nderket, Tigapanah, Kabanjahe and Berastagi) starting from April until Mei 2014.The sample obtained with the method of accidental sampling and retrieved farmers (10), collector (17),traditional market (12) and slaughterhouse (1).The data analysis was done by using multiple linear regression. The result showed that the existing marketing channels in Karo District comprises three pattern marketing ; pattern I: farmer - traditional market - consumer, pattern II: farmer - collector - traditinal market - consumer, pattern III: farmer - collector - slaughterhouse - traditional market - consumer.Efficiency marketing that 99,70\% simultaneously affected by the independent variable (margins of marketing and marketing pattern) positive effect on the efficiency of marketing $\left(R^{2}=0,997\right)$. The highest marketing margin in pattern III which was Rp. $6.026,67$ ( $\mathrm{kg}$ live weight) and the low of contained on the pattern I Rp. 5.926,6 ( $\mathrm{kg}$ live weight). And profits at the pattern III Rp. 2.088 ( $k g$ live weight), while the highest profit on patterns I Rp. 5.486,67(kg live weight). The efficiency of marketing on the pattern I of 86,69\%, pattern II 86,71\% and pattern III 86,59\%. The conclusions of this research that increasingly distribution channel increase the marketing margin.
\end{abstract}

Keyword :beef cattle, marketing margins, marketing efficiency, marketing pattern.

\begin{abstract}
ABSTRAK
Penelitian bertujuan untuk mengetahui faktor-faktor yang mempengaruhi perbedaan harga daging sapi, sistematis penyaluran daging sapi, sistem tataniaga efisiensi pemasaran. Penelitian ini dilaksanakan di Kabupaten Karo di 4 Kecamatan (TigaNderket, Tigapanah, Kabanjahe dan Berastagi) mulai bulan April sampai Mei 2014. Sampel diperoleh dengan metode accidental sampling dan diperoleh 10 orang peternak, 12 pedagang pengumpul, 17 pedagang pasar dan 1 rumah potong hewan. Analisis data dilakukan dengan menggunakan analisis regresi linier berganda. Penelitian menunjukkan saluran pemasaran yang ada di Kabupaten Karo terdiri dari tiga pola pemasaran yaitu : pola I : Peternak - Pedagang Pasar - Konsumen, Pola II : Peternak - Pedagang Pengumpul - Pedagang Pasar - Konsumen, Pola III: Peternak - Pedagang Pengumpul - RPH - Pedagang Pasar - Konsumen. Hasil penelitian ini bahwa 99,70\% (efisiensi pemasaran) secara bersama-sama dipengaruhi oleh variabel independen (marjin pemasaran dan pola pemasaran) berpengaruh positif terhadap efisiensi pemasaran. Marjin pemasaran tertinggi pada pola III sebesar Rp. 6.026,67 (kg bobot hidup) dan terendah pada pola I sebesar Rp. 5.926,67 (kg bobot hidup). Keuntungan pada pola III sebesar Rp.2.088 (kg bobot hidup), sedangkan keuntungan tertinggi pada pola I sebesar Rp.5.486,67 (kg bobot hidup). Efisiensi pemasaran pada Pola I sebesar 86,69\%, Pola II 86,71\% dan Pola III 86,59\%. Kesimpulan dari penelitian ini bahwa semakin panjang saluran distribusi maka marjin pemasaran semakin besar.
\end{abstract}

Kata Kunci : Sapi potong, Marjin Pemasaran, Efisiensi Pemasaran, Pola Pemasaran 


\section{PENDAHULUAN}

Seiring bertambahnya jumlah penduduk maka kebutuhan akan makanan yang bermutu tinggi dalam jumlah yang banyak semakin meningkat. Dalam hal inilah peran peternakan dapat memberikan sumbangsih yang besar. Untuk memenuhi kebutuhan makan manusia yang semakin meningkat memerlukan peternakan yang khusus menghasilkan produk - produk tertentu. Produk peternakan meliputi daging susu dan telur. Seiring bertambahnya waktu dan tingkat pendidikan maka kebutuhan akan protein hewani meningkat. Tingginya harga daging sapi dipasar-pasar tradisional disebabkan oleh beberapa faktor,yaitu : 1. Harga sapi hidup dari para peternak atau pengusaha yang masih sangat tinggi, 2. Berkurangnya jumlah pasokan daging sapi dan, 3. Naiknya harga BBM belakangan ini sehingga menyebabkan harga daging sapi pun meningkat. Belum diketahui pasti apa penyebabnya perbedaan harga daging sapi dimasing-masing penjual tersebut. Untuk itu perlu dilakukan penelitian mengenai analisis harga daging sapi di pasar-pasar tradisional Kabupaten Karo.

Pasar juga tempat terjadinya mekanisme pasar yang mencakup informasi tentang kualitas dan harga dari barang yang diperdagangkan mekanisme tersebut menuntut penyaluran atau pemasaran produk dari pedagang ke konsumen dan segmen pasar yang dituju. Pemasaran atau tataniaga sebagai salah satu komponen pasca produksi perlu mendapatkan perhatian yang serius dalam usaha peternakan.

Penetapan saluran pemasaran ternak sapi potong juga menjadi sangat penting untuk peternak, sebab dapat mempengaruhi kelancaran penjualan, tingkat keuntungan, model, dan resiko. Saluran pemasaran merupakan saluran atau jalur yang digunakan baik secara langsung maupun tidak langsung untuk memudahkan suatu produk bergerak dari produsen sampai berada di tangan konsumen. Dalam pemasaran ternak sapi potong penetapan harga jual menjadi hal yang perlu diperhatikan karena akan memberi dampak terhadap konsumen akhir. Penetapan jalur penjualan dan harga sapi potong merupakan faktor yang penting dalam menentukan keefisienan kegiatan pemasaran.

Sehubungan dengan hal pemasaran diatas penulis mencoba menganalisis faktor-faktor yang mempengaruhi harga daging sapi di pasar-pasar tradisional kabupaten karo dan untuk mengetahui sistematis penyaluran daging sapi dari rumah potong hewan hingga sampai ke penjual pasar - pasar tradisional. 
Perbedaan harga merupakan penyebab terjadinya perdagangan antar lokasi, yakni produk-produk cenderung mengalir dari daerah surplus kedaerah defisit, sampai perbedaan harga mendekati biaya tataniaga yang dikeluarkan (Simamora, 2007).

Pedagang dalam hal untuk mempertahankan perdagangan antar daerah diupayakan agar margin tataniaga seminimal mungkin sehingga mempunyai daya saing dengan produk sejenis di daerah tujuan pemasaran. Hal ini berarti bahwa sistem tataniaga sejak dari produsen hingga ke konsumen perlu dikoordinasikan agar tercapai tingkat efisiensi yang di harapkan (Tomek et al, 1997).

\section{BAHAN DAN METODE PENELITIAN}

\section{Tempat dan Waktu Penelitian}

Penelitian ini dilaksanakan di beberapa pasar tradisional Kabupaten Karo di 4 Kecamatan (Tiganderket, Tigapanah, Kabanjahe dan Berastagi) pada April sampai Juni 2014.

\section{Metode Penelitian}

\section{Penentuan Responden dan Analisis Harga Daging}

Responden terdiri dari pada pedagang penjual daging sapi di pasar-pasar tradisional Kabupaten Karo. Metode penelitian digunakan adalah metode survei dengan unit responden pedagang yang menjual daging sapi. Responden yang berasal dari 6 pasar tradisional yang dipilih secara acak dari 17 kecamatan yang terdapat di Kabupaten Karo, tiap pasar terdiri dari 5 orang pedagang daging sapi. Dari masing-masing pasar responden dipilih secara accidental sampling yaitu responden pada saat didatangi ke pasar dan bersedia untuk di wawancarai serta memiliki data yang di perlukan (Khoirunnisa, 2008).

\section{Pengumpulan Data}

Sumber data yang digunakan pada penelitian ini adalah :

a. Data primer yaitu data yang bersumber dari hasil wawancara langsung dengan responden yaitu peternak sapi potong di Kabupaten Karo. Mengenai pemasaran ternak sapi potong yang hususnya mengenai penjualan dan lain sebagainya yang berkaitan dengan penelitian.

b. Data sekunder adalah data yang bersumber dari buku-buku, laporan-laporan, badan pusat statistik, dan instansi terkait lainnya. 


\section{Parameter Penelitian}

1. Petani ternak sapi potong adalah petani ternak yang mengusahakan (berternak) sapi potong serta merupakan milik sendiri atau orang lain sebanyak 2-4 ekor .

2. Pedagang Pengumpul adalah kelompok pedagang yang kegiatannya membeli produksi dari produsen secara langsung atau melalui lembaga pemasaran lain kemudian dikumpulkan dan dijual kepada pedagang lain.

3. RPH/jagal adalah orang/lembaga yang membeli sapi potong dalam keadaan hidup untuk dikonsumsi maupun dijual lagi dalam kondisi yang telah berubah bentuk.

4. Pedagang pasar adalah kelompok pedagang yang kegiatannya memasarkan produk sapi potong kepada konsumen.

5. Harga jual sapi potong adalah harga yang diterima peternak dari lembagapemasaran dan yang di hitung dalam satuan rupiah per kilogram.

6. Harga beli sapi potong adalah harga yang dibayarkan oleh masing-masing lembaga pemasaran dengan satuan $\mathrm{Rp} / \mathrm{kg}$.

7. Lembaga pemasaran adalah lembaga-lembaga atau badan-badan yang didirikan.

8. dan dikelola oleh blantik, pedagang pengumpul, jagal dan pedagang pengecer yang melaksanakan aktifitas pemasaran.

9. Saluran pemasaran sapi potong adalah rantai pemasaran sapi potong dari produsen sampai ke konsumen.

10. Biaya pemasaran adalah biaya yang dikeluarkan oleh lembaga pemasaran dalam memasarkan sapi potong dengan satuan $\mathrm{Rp} / \mathrm{Kg}$.

11. Keuntungan lembaga pemasaran adalah selisih antara nilai penjualan dengan nilai pembelian dengan satuan $\mathrm{Rp} / \mathrm{Kg}$.

12. Marjin pemasaran adalah merupakan jumlah biaya yang dikeluarkan dan banyaknya jumlah keuntungan yang diterima oleh tiap lembaga pemasaran terhadap saluran pemasaran sapi potong dengan satuan $\mathrm{Rp} / \mathrm{Kg}$.

13. Share biaya/keuntungan lembaga pemasaran adalah bagian biaya/keuntungan lembaga pemasaran.

\section{Analisis Data}

Analisa data yang digunakanpada penelitian ini adalah :

1. Untuk mengetahui bentuk saluran pemasaran ternak sapi potong digunakan analisa deskriptif 
2. Untuk mengetahui margin tiap lembaga pemasaran dan saluran pemasaran di gunakan rumus sebagai berikut :

a. Margin tiap lembaga pemasaran ternak sapi potong

$$
\mathbf{M}=\mathbf{H p}-\mathbf{H b}
$$

Keterangan :

$\mathrm{M}=$ Margin lembaga Pemasaran

$\mathrm{Hp} \quad=$ Harga penjualan $(\mathrm{Rp} / \mathrm{kg})$

$\mathrm{Hb} \quad=$ Harga Pembelian $(\mathrm{Rp} / \mathrm{kg})$

b. Margin tiap saluran pemasaran

$$
\mathrm{Mt}=\mathrm{M1}+\mathrm{M} 2+\ldots . .+\mathrm{Mn}
$$

Keterangan :

Mt = Margin Saluran Pemasaran

M1 = Margin Pemasaran Lembaga Pemasaran ke-1

M2 = Margin Pemasaran Lembaga Pemasaran ke-2

$\mathrm{Mn}=$ Margin Pemasaran Lembaga Pemasaran ke-n

3. Untuk mengetahui besarnya keuntungan dari masing-masing lembaga pemasaran digunakan rumus

$$
\Pi=\text { ML-TC }
$$

Keterangan:

$\Pi \quad=$ KeuntungaLembaga Pemasaran $(\mathrm{Rp} / \mathrm{kg})$

$\mathrm{ML} \quad=$ Margin lembaga Pemasaran $(\mathrm{Rp} / \mathrm{kg})$

TC = Biaya total pemasaran yang dikeluarkan tiap lembaga pemasaran $(\mathrm{Rp} / \mathrm{kg})$

4. Untuk mengetahui keuntungan pemasaran dari tiap saluran pemasaran digunakan rumus:

$$
\Pi t=\Pi 1+\Pi 2+\ldots . . \Pi n
$$

Keterangan :

ПI $=$ Keuntungan saluran pemasaran

П1 = Keuntungan lembaga pemasaran ke-1

П2 =Keuntungan lembaga pemasaran ke-2

Пn = Keuntungan lembaga pemasaran ke-n

5. Untuk mengetahui efisiensi saluran pemasaran digunakan rumus:

$$
\mathbf{E p}=\underline{\mathrm{BPx}}_{\mathrm{NP}} 100 \%
$$


Keterangan:

$\mathrm{EP} \quad=$ Efisiensi Pemasaran $(\mathrm{Rp} / \mathrm{kg})$

$\mathrm{BP}=$ Total harga di tingkat peternak $(\mathrm{Rp} / \mathrm{kg})$

$\mathrm{NP} \quad=$ Total harga di tingkat konsumen $(\mathrm{Rp} / \mathrm{kg})$

\section{HASIL DAN PEMBAHASAN}

\section{Karakteristik Responden}

Karakteristik responden (pedagang daging sapi) seperti yang tertera pada Tabel $1 \mathrm{di}$ pasar-pasar tradisional Kabupaten Karosebagian besar berumur 25-50 tahun, dan termasuk dalam kelompok umur produktif. Pendidikan responden peternak dan lembaga pemasaran sebagian besar pada tingkat SLTP dan SLTA, terutama produsen dan pedagang pasar. Mengacu pada tingkat pendidikan dapat dikategorikan tinggi, hal ini diharapkan dapat mendukung dalam penyerapan berbagai informasi tentang kegiatan yang terkait dengan bidang usaha peternakan maupun tentang pemasaran.

Tabel 1. Identitas Responden Lembaga Pemasaran

\begin{tabular}{|c|c|c|c|c|}
\hline Identitas & $\begin{array}{c}\text { Peternak } \\
\mathrm{N}=10\end{array}$ & $\begin{array}{l}\text { P. Pengumpul } \\
\quad \mathrm{N}=12\end{array}$ & $\begin{array}{c}\text { P. Pasar } \\
\mathrm{N}=17\end{array}$ & $\begin{array}{l}\mathrm{RPH} \\
\mathrm{N}=1\end{array}$ \\
\hline \multicolumn{5}{|l|}{ Umur (tahun) } \\
\hline $25-50$ & $10(100 \%)$ & $12(100 \%)$ & $15(88,23 \%)$ & $1(100 \%)$ \\
\hline $51-60$ & - & - & $2(11,76 \%)$ & - \\
\hline$>60$ & - & - & - & - \\
\hline \multicolumn{5}{|l|}{ Pendidikan } \\
\hline Tamat SD & $2(20 \%)$ & $3(25 \%)$ & $5(29,4 \%)$ & - \\
\hline Tamat SLTP & $3(30 \%)$ & $5(41,67 \%)$ & $10(58,82 \%)$ & - \\
\hline Tamat SLTA & $5(50 \%)$ & $4(33,33 \%)$ & $2(11,76 \%)$ & $1(100 \%)$ \\
\hline \multicolumn{5}{|c|}{ Pengalaman (tahun) } \\
\hline $1-5$ & $2(20 \%)$ & $3(25 \%)$ & $2(11,76 \%)$ & - \\
\hline $6-10$ & $4(40 \%)$ & $4(33,33 \%)$ & $6(35,29 \%)$ & - \\
\hline$>10$ & $4(40 \%)$ & $5(41,67 \%)$ & $9(52,94 \%)$ & $1(100 \%)$ \\
\hline
\end{tabular}

Pengalaman beternak atau usaha pemasaran sapi potong cukup bervariasi. Pada produsen yang mempunyai pengalaman beternak di atas 10 tahun sebanyak 4 orang (40\%), sisanya masing-masing sebanyak 2 dan 4 orang yang mempunyai pengalaman 5-10 tahun dan 1-5 tahun. Pengalaman responden pada lembaga pemasaran sebagian besar berada pada kisaran 6-10 tahun. Pengalaman responden di bidang usaha beternak maupun usahapemasaran daging yang semakin lama diharapkan responden tersebut dapat lebih 
mengetahui dan mendalami tentang manajemen usaha yang dilakukan, sehingga mampu mengantisipasi persoalan yang ada.

Menurut Mosher (1965) semakin tinggi tingkat pengetahuan dan keterampilan mengakibatkan petani peternak lebih dinamis, aktif dan terbuka dalam mengadopsi suatu teknologi. Kondisi ini penting mengingat saat ini diperlukan pengetahuan dan pemahaman secara baik tentang perkembangan usaha yang semakin cepat baik teknologi maupun aspek pemasaran.

\section{Saluran Pemasaran}

Berdasarkan hasil penelitian menunjukkan bahwa saluran pemasaran yang ada di Kabupaten Karo khususnya di 4 Kecamatan (Tiga Nderket, Tigapanah, Kabanjahe dan Berastagi)terdiri dari tiga pola pemasaran yaitu:

a) Pola I : Peternak - Pedagang - Pasar- Konsumen

b) Pola II : Peternak - Pedagang - Pengumpul - Pedagang Pasar - Konsumen

c) Pola III : Peternak- Pedagang Pengumpul - RPH - Pedagang Pasar- Konsumen.

Petani ternak sapi potong adalah petani ternak yang mengusahakan (berternak) sapi potong serta merupakan milik sendiri atau orang lain sebanyak 2-4 ekor. Pedagang Pengumpul adalah kelompok pedagang yang kegiatannya membeli produksi dari produsen secara langsung atau melalui lembaga pemasaran lain kemudian dikumpulkan dan dijual kepada pedagang lain. RPH/jagal adalah orang/lembaga yang membeli sapi potong dalam keadaan hidup untuk dikonsumsi maupun dijual lagi dalam kondisi yang telah berubah bentuk. Pedagang pasar adalah kelompok pedagang yang kegiatannya memasarkan produk sapi potong kepada konsumen.

\section{Marjin Pemasaran}

Marjin pemasaran yaitu selisih harga jual dengan harga beli dan merupakan salah satu indikator yang digunakan untuk mengukur tingkat efisiensi suatu sistem pemasaran. Marjinpemasaran terdiri dari biaya pemasaran dan keuntungan lembaga pemasaran. Dalam pembahasan ini akan diuraikan marjin pemasaran melalui dari tingkat pedagang pengumpul desa sampai ke pedagang besar pada masing-masing saluran pemasaran.

Analisis mengenai margin pemasaran dan Farmer' Sharedilakukan dengan penghitungan margin pemasaran yang diperoleh oleh lembaga pemasaran,berdasarkan pengurangan harga penjualan dengan harga pembelian dan biaya yangdikeluarkan. Hasil 
perhitungan terhadap biaya, keuntungan, marginpemasaran, dan sebaran margin pemasarannya dianalisis lebih lanjut untukmengetahui besarnya margin yang diperoleh masing- masing lembaga pemasarandan tingkat efisiensi saluran.

Total marjin pemasaran (Tabel 2) pada masing - masing saluran tertinggi diperoleh pada pola III yaitu sebesar Rp. 6.026,67 dan terendah terdapat pada pola I yaitu sebesar Rp. 5.926, 67. Menurut Swastha (1991) besarnya marjin tersebut mengindikasikan bahwa semakin panjangsaluran distribusi maka marjin pemasaran akan semakin besar, sebaliknya semakin pendek saluran distribusi maka marjin pemasaran akan semakin kecil/berkurang. Lebih lanjut Saliem (2004) menyatakan tujuan analisis margin pemasaran bertujuan untuk melihat efisiensi pemasaran yang diindikasikan oleh besarnya keuntungan yang diterima oleh masing-masing pelaku pemasaran.

Tabel 2. Marjin Pemasaran Daging Sapi Pada Masing-masing Saluran Pemasaran di Kabupaten Karo

\begin{tabular}{llccc}
\hline Pola & Saluran Pemasaran & $\begin{array}{c}\text { Harga Jual } \\
(\mathbf{R p} / \mathbf{K g})\end{array}$ & $\begin{array}{c}\text { Harga Beli } \\
(\mathbf{R p / K g})\end{array}$ & $\begin{array}{c}\text { Marjin } \\
\text { Pemasaran }\end{array}$ \\
\hline I & Peternak & 38.633 & - & - \\
& P.Pasar & 44.560 & 38.633 & 5.926 \\
& Total & & & 5.926 \\
& Peternak & 38.700 & - & - \\
& P.Pengumpul & 41.214 & 38.700 & 2.514 \\
& P.Pasar & 44.628 & 41.214 & 3.414 \\
& Total & & & 5.938 \\
& Peternak & 38.933 & - & - \\
& P. Pengumpul & 41.420 & 38.933 & 2.486 \\
& RPH & 42.500 & 41.420 & 1.080 \\
& P.Pasar & 44.960 & 42.500 & 2.460 \\
\hline \multicolumn{2}{l}{} & & & 6.026 \\
\hline
\end{tabular}

Sumber: Data Primer Penelitian ( 2014)

Tabel 3. Biaya Pemasaran dan Keuntungan yang Diterima Oleh Lembaga Pemasaran Pada Masing-masing Saluran

\begin{tabular}{llcc}
\hline Pola & Saluran Pemasaran & Biaya Pemasaran $(\mathrm{Rp})$ & Keuntungan $(\mathrm{Rp})$ \\
\hline I & Peternak & - & - \\
& P.Pasar & $440(7,43 \%)$ & $5.487(92,57 \%)$ \\
II & Peternak & - & - \\
& P.Pengumpul & $371(14,78 \%)$ & $2.143(85,22 \%)$ \\
& P.Pasar & $459(13,44 \%)$ & $2.956(86,56 \%)$ \\
III & Peternak & - & - \\
& P.Pengumpul & $362(14,56 \%)$ & $2.125(85,44 \%)$ \\
& RPH & $300(27,78 \%)$ & $780(72,22 \%)$ \\
& P.Pasar & $372(15,13 \%)$ & $2.088(84,87 \%)$ \\
\hline
\end{tabular}

Sumber: Data Primer Penelitian ( 2014) 
Semakin tinggi proporsi harga yang diterima produsen, semakin efisien sistem pemasaran tersebut. Besarnya keuntungan yang diterima oleh masing-masing pelaku pemasaran relatif terhadap harga yang dibayar konsumen dan atau relatif terhadap biaya pemasaran terkait dengan peran yang dilakukan oleh masing-masing pelaku.

Tabel 3 di atas diketahui bahwa biaya pemasaran keuntungan yang terkecil diterima oleh pedagang pasar pada saluran III yaitu hanya sebesar Rp.2.088/Kg dari harga jual kepada konsumen, sedangkan keuntungan tertinggi diperoleh pedagang pasar pada saluran I yaitu sebesar Rp.5.486,67/Kg dari harga jual kepada konsumen. Hal ini dikarenakan saluran pemasaran yang di lalui cukup pendek sehingga dapat menekan biaya pemasaran dan marjin pemasaran.

\section{Efisiensi Pemasaran Daging Sapi}

Masalah pemasaran komoditi pertanian pada dasarnya adalah bagaimana menyalurkan produk-produk pertanian dari produsen kepada konsumen dengan harga yang wajar dan biaya pemasaran minimal. Menurut Soekartawi (1997), Efisiensi pemasaran yang efisien jika biaya pemasaran lebih rendah daripada nilai produk yang dipasarkan, semakin rendah biaya pemasaran dari nilai produk yang dipasarkan semakin efisien melaksanakan pemasaran. Perhitungan efisiensi pemasaran dapat dilihat pada Tabel 6.

Berdasarkan Tabel 4 hasil penelitian menunjukkan bahwa efisiensi pemasaran pada Pola I sebesar 86,69\%, Pola II 86,71\% dan Pola III 86,59\%. Menurut Sudiyono(2002) strategi yang dapat dilakukan oleh produsen dan lembaga pemasaran untuk meningkatkan efisiensi pemasaran adalah dengan memperluas pasar dan memperkecil marjin pemasaran. Strategi memperluas pasar dapat ditempuh dengan memperbesar permintaan konsumen dan pelaksanaan pemasaran tertata.

Menurut Downeydan Erickson(1992) bahwa pemasaran hasil pertanian ditinjau dari bagian harga yang diterima oleh petani produsen dikatakan efisien apabila harga jual petani lebih dari $40 \%$ dari harga tingkat konsumen. Mengacu pada pendapat tersebut hasil penelitian menunjukkan bahwa pemasaran daging sapi di Kabupaten Karo sudah efisien, dengan tingkat efisiensi sebesar $86,66 \%$. Atau dapat dikatakan bahwa bagian harga yang dinikmati oleh produsen sebesar $86,66 \%$ terhadap harga ditingkat konsumen. Hasil perhitungan ini menunjukkan bahwa pemasaran daging sapi ditinjau dari bagian harga yang diterima oleh peternak sudah melebihi batas $40 \%$. 
Tabel 4. Efisiensi pemasaran daging sapidi Kabupaten Karo

\begin{tabular}{|c|c|c|c|}
\hline $\begin{array}{c}\text { Pola } \\
\text { Pemasaran }\end{array}$ & $\begin{array}{r}\text { Harga di tingkat peternak } \\
\text { (a) } \\
\\
\text {....... (Rp. }\end{array}$ & $\begin{array}{l}\text { Harga di tingkat } \\
\text { konsumen (b) } \\
\text {..... }\end{array}$ & $\begin{array}{c}\text { Efisiensi pemasaran } \\
\text { (a/b) } x 100 \% \\
\ldots \ldots(\%) \ldots \ldots \\
\end{array}$ \\
\hline Pola I & $38.633,33$ & $44.560,00$ & 86,69 \\
\hline Pola II & $38.700,00$ & $44.628,57$ & 86,71 \\
\hline Pola III & $38.933,33$ & $44.960,00$ & 86,59 \\
\hline Rata-rata & $38.755,55$ & $44.716,19$ & 86,66 \\
\hline
\end{tabular}

Sumber: Data Primer Penelitian ( 2014)

\section{Faktor-Faktor yang Mempengaruhi Efisiensi Pemasaran Daging Sapi di Kabupaten} Karo

Efisiensi pemasaran sapi potong sangat diharapkan oleh pelaku pasar mulai dari produsen sampai konsumen. Untuk mengetahui faktor-faktor apa saja yang mempengaruhi efisiensi pemasaran dicoba dianalisis dengan menggunakan modelregresi linier berganda. Sebagai variabel dependen (Y) adalah efisiensi pemasaransedangkan variabel independen adalah $\mathrm{X} 1$ = margin pemasaran, dan $\mathrm{X} 2$ = pola pemasaran. Hasil penelitian menunjukkan bahwa persamaan regresi yang dihasilkan adalah sebagai berikut:

$\mathrm{Y}=99,424-0,002 \mathrm{X}_{1}-0,071 \mathrm{X}_{2}$ dengan Nilai $\mathrm{R}^{2}=0,997$

Berdasarkan uji statistik dengan menggunakan dengan uji $\mathrm{F}$ menunjukkan bahwa efisiensi pemasaran dipengaruhi sangat nyata $(\mathrm{P}<0,01)$ dipengaruhi oleh variabel margin sedangkan pengaruh pola pemasaran tidak nyata terhadap efisiensi pemasaran. Hasil ini sesuai pendapat Sudiyono(2002) bahwa efisiensi pemasaran antara lain dipengaruhi oleh marjin pemasaran, harga, dan tingkat persaingan pasar. Hasil penelitian juga menunjukkan bahwa nilai koefisien determinasi $\left(\mathrm{R}^{2}\right)$ sebesar 0,997 , yang berarti sebanyak 99,70\% variabel dependen (efisiensi pemasaran) secara bersama-sama dipengaruhi oleh variabel independen (margin pemasaran dan pola pemasaran), sedangkan sisanya sebesar $0,30 \%$ dipengaruhi oleh faktor lain yang tidak termasuk dalam model. Secara parsial dengan menggunakan uji t menunjukkan bahwa variabel X1 (margin pemasaran) berpengaruhsecara sangat nyata $(\mathrm{P}<0,01)$ terhadap efisiensi pemasaran sedangkan pola pemasaran tidak berpengaruh nyata terhadap efisiensi pemasaran $(\mathrm{P}>0,01)$.

Nilai koefisien regresi X1 (margin pemasaran) diperoleh hasil sebesar-0,002. Hasil ini dapat diartikan bahwa setiap kenaikan 1\% marjin akan menurunkan efisiensi pemasaran sebesar $0,002 \%$. Selanjutnya pada variabel X2 (pola pemasaran) diperoleh nilai koefisien regresi sebesar -0,071 yang dapat diartikan bahwa setiap kenaikan $1 \%$ pola akan menurunkans efisiensi pemasaran sebesar $0,071 \%$. 


\section{KESIMPULAN}

1. Berdasarkan hasil penelitian dapat disimpulkan bahwa variabel marjin pemasaran dan pola pemasaran secara bersama-sama berpengaruh positif terhadap efisiensi pemasaran.

2. Efisiensi pemasaran dipengaruhi oleh variabel pola pemasaran dan marjin pemasaran sebesar 99,70\%, dan sisanya sebanyak 0,30\% dipengaruhi oleh variabel lain diluar model.

3. semakin panjang saluran distribusi maka marjin pemasaran akan semakin besar, sebaliknya semakin pendek saluran distribusi maka marjin pemasaran akan semakin kecil/berkurang.

\section{DAFTAR PUSTAKA}

Downey dan Erickson. 1992. Manajemen Agribisnis. Erlangga. Jakarta.

Khoirunnisa, 2008. Analisis Permintaan Daging Ayam Broiler Konsumen Rumah Tangga di Kecamatan pancoran Mas Kota depok. Skripsi. Program Studi Sosial Ekonomi

Mosher, A.T. 1965. Menggerakkan dan Membangun Pertanian. CV Yasaguna, Jakarta.

Nugraha, A. P, 2006. Analisis Efisiensi Pemasaran Jamur Tiram Segar di Bogor Provinsi Jawa Barat. IPB_press. Bogor.

Saliem, H.P. 2004. Analisis Margin Pemasaran : Salah Satu Pendekatan dalam Sistem Distribusi Pangan. DalamProspek Usaha dan Pemasaran Beberapa Komoditas Pertanian. Monograph Series No. 24. Pusat Penelitian dan Pengembangan Sosial Ekonomi Pertanian. Bogor.

Simamora. 2007. Analisis Sistem Tataniaga. IPB_Press. Bogor.

Soekartawi. 1997. Analisis Fungsi Produksi. Jakarta: Rajawali Pers. PT. Raja Grafindo Persada

Sudiyono, A. 2002. Pemasaran Pertanian. UMM_Press. Malang.

Swastha. 1991. Manajemen Pemasaran Modern. Liberty Offest. Yogyakarta.

Tomek, et al., 1997. Agriculture Product Price Cornell. Universitay-Press. London. 